\title{
Birds and Mammals of the Wakha Valley in Northern India
}

\author{
Raza M1,2*, Namgail T1 ${ }^{1}$ and Khan $\mathrm{A}^{2}$ \\ ${ }^{1}$ Snow Leopard Conservancy-India Trust, Ladakh, India \\ ${ }^{2}$ Aligarh Muslim University, Uttar Pradesh, India
}

*Corresponding author: Mohd Raza, Snow Leopard Conservancy India Trust, Korban House, Changspa, Sheldan, Leh-194101, Ladakh, India, Email: razapodrigs@gmail.com

\section{Research Article \\ Volume 2 Issue 6}

Received Date: November 22, 2019

Published Date: December 30, 2019

DOI: $10.23880 /$ izab-16000193

\section{Abstract}

Ladakh in northern India harbours a diverse assemblage of birds and mammals. The species in the region show close affinity with the Palaearctic bio-geographic realm. We conducted a survey on mammals and birds in the Wakha Valley of Kargil district in Ladakh in 2013. This area remains virtually unknown in terms of its biodiversity. During the survey, we recorded mammalian herbivores like the Asiatic ibex Capra ibex siberica, Ladakh urial Ovis vignei vignei and long-tailed marmot Marmota caudata. Mammalian carnivores included the charismatic snow leopard Panthera uncia, Tibetan wolf Canis lupus chanko, Himalayan brown bear Ursus arctos isabellinus and red fox Vulpes v. montana. Avifauna comprised 45 species belonging to 19 families and five orders. Most of the bird species were of the order Passeriformes (36 species). Forty nine percent of the species were resident, while the rest were migratory that visit the area in summer as well as in winter. Bird species were mostly observed in riverine habitats. This is the first documentation of the diversity of birds and mammals in the Wakha valley of Ladakh.

Keywords: Birds; Mammals; Kargil; Ladakh; Trans-Himalaya

\section{Introduction}

Ladakh, spanning over an area of about $85,000 \mathrm{~km}^{2}$ lies in the rain shadow of the Greater Himalaya. Due to its location at the boundary between two bio-geographic realms, it harbours a diverse assemblage of birds and mammals [1]. Mammalian fauna comprises 34 species which include eight wild ungulates and twelve carnivores [2-3]. Over 320 species of birds have been reported from the region $[2,4,5]$.

Ladakh was an important hunting area for the British officials in the $20^{\text {th }}$ Century, and anecdotal and preliminary information on mammals of the region can be found in the diaries of many British hunters [6]. However, scientific investigation on mammals began only in the 1970s [7], and more detailed researches on the taxon were conducted $[3,8,9]$ followed by species specific surveys to know the status and distribution of mammals such as Ladakh urial [10], Tibetan gazelle [11,12], Tibetan argali [13], and the snow leopard $[14,15]$.

Early expeditions to study bird species of Ladakh were initiated in 1859(16). Thereafter, birds were studied by several researchers [17-19]. After the Independence of India, Ladakh remained closed for western explorers till 
late 1970. Holmes visited Ladakh in 1986 to study the distribution of birds in the Suru Valley, and then many more followed suit [4,5,20-22].

Most of the studies on birds and mammals in Ladakh were carried out in the eastern part, and the Kargil area remained virtually unexplored. Only a few studies on birds and mammals in this area [21-24] were carried out. Recognizing this dearth of information, we conducted a survey in the Wakha valley of Kargil to document the birds and mammals of the region.

\section{Study Area}

Wakha Valley lies in the Kargil district of western Ladakh. Located at a distance of $47 \mathrm{~km}$ from the Kargil town, it has a human population of about 10,000 individuals. The valley is characterized by rugged terrain with altitude ranging from $3200 \mathrm{~m}$ to $4600 \mathrm{~m}$ asl. Precipitation is generally in the form of snowfall during winter. Temperature in the valley plummets to $-37^{\circ} \mathrm{C}$ in winter and surges upto $34^{\circ} \mathrm{C}$ in summer.

Vegetation in the region is characterized by sub-alpine meadow [25]. Primary productivity is low, and the area is virtually devoid of forest cover except for isolated patches of junipers and planted varieties of poplar and willow along major water courses [9]. Tree species such as willow Salix spp., Juniper Juniperus semiglobosa and Beluta utilis are confined to riparian areas [25].

People are dependent on agriculture and livestock farming for livelihood. Water for irrigation, drinking and livestock is sourced from Wakha River, which originates from the Kanji glacier. Agricultural season starts in May and ends in September. Barley and wheat, the staple crops of the region are cultivated during this short growth season. Sheep, goat, yak, cow and donkey are the main livestock types reared by farmers.

\section{Methods}

Data on mammals were collected in February and March, while data on birds were collected in April and May, 2013. We stratified the valley into five habitat types' namely riverine, agricultural, alpine meadows, steppe vegetation and barren areas. Riverine areas included areas along river and streams with willow and poplar plantation whereas alpine meadows were characterised by gentle slopes with forb vegetation. Steppe vegetation areas are habitats with Artemesia spp. and Tanacetum spp. as dominant species.

For the mammals, we scanned the area from vantage points. Equal amount of time was spent in each habitat type. Stratification was necessary as the area has a mosaic of different habitat types. We relied on direct sightings in case of mammalian herbivores, and on signs in case of carnivorous species. Whenever animals were sighted, we recorded the GPS coordinates, altitude and slope angle of their locations. In case of the ungulates, we also recorded the number of individuals in a group, age and sex composition. The age and sex of the animals were determined through observing body size, distinct markings, and horn size [2,7].

To observe birds we walked along the river bank with willow and juniper trees, alpine meadows and trails. We stopped at every 100 meter and spent 10 minutes scanning the trees and vegetated slopes for birds. Whenever a bird was located, we noted down the species name, number of individuals, habitat type and GPS coordinates. We walked in the morning between 0600 and $0900 \mathrm{hrs}$ and in the evening between 1600 and 1830 hrs. Birds were identified using the pocket guide to the birds of the Indian subcontinent [26]. Since no animal was handled during the study we did not need ethical clearance.

\section{Results}

\section{Mammals}

A total of 8 mammalian species were recorded in the Wakha Valley in an area ranging in altitude from 3200 to $4500 \mathrm{~m}$ asl. We counted a total of 93 individuals of Asiatic ibex in 13 groups and 115 Ladakh urial in three groups. We also observed 10 long-tailed marmots, 3 cape hare along the trails (Table 1). We did not observe any large predator except 8 red foxes. We however observed a lot of signs of the Himalayan brown bear (24 signs), Tibetan wolf (18) and snow leopard (10).

\begin{tabular}{|c|c|c|c|c|c|c|}
\hline Species & Individuals & Groups & Mean group size & Adult Male & Adult Female & Sub-adult \\
\hline Asiatic ibex & 93 & 13 & 7 & 41 & 33 & 19 \\
\hline Ladakh urial & 115 & 3 & 39 & 17 & 46 & 52 \\
\hline
\end{tabular}

Table 1: Wild ungulates observed in the Wakha Valley, Kargil. 
Ladakh urials were found in undulating areas where slope angle was less than 30 degrees whereas ibexes were seen in areas with broken and rugged terrains with more than 30 degrees slope angle. Marmots were mostly observed in alpine meadows (Figure 1). The signs of snow leopard were found mostly along valley bottoms and ridgelines in riverine, alpine meadows and steppe vegetation areas. Brown bear signs were concentrated in riverine and rocky habitats whereas red fox and wolf signs were encountered mostly in alpine meadows and steppe vegetation areas (Figure 2).

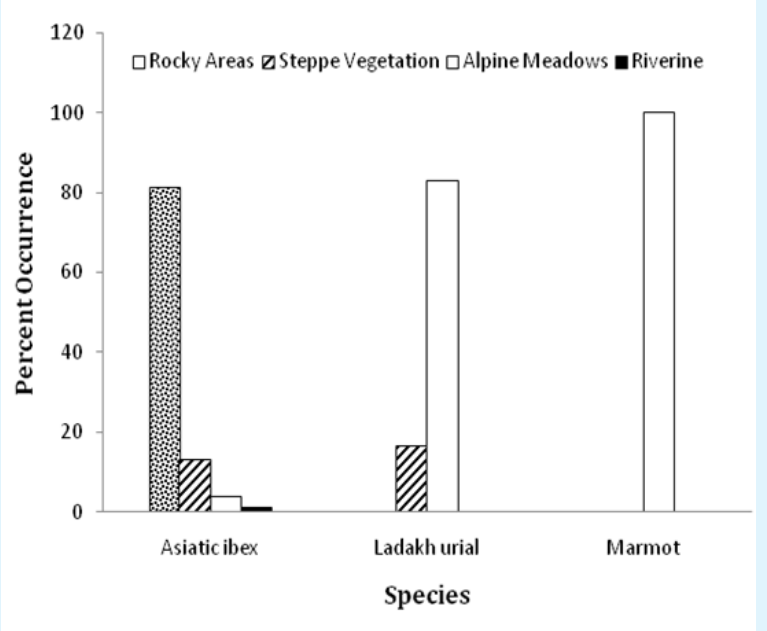

Figure 1: Percent occurrence of herbivore species in different habitat types in the Wakha Valley, Kargil.

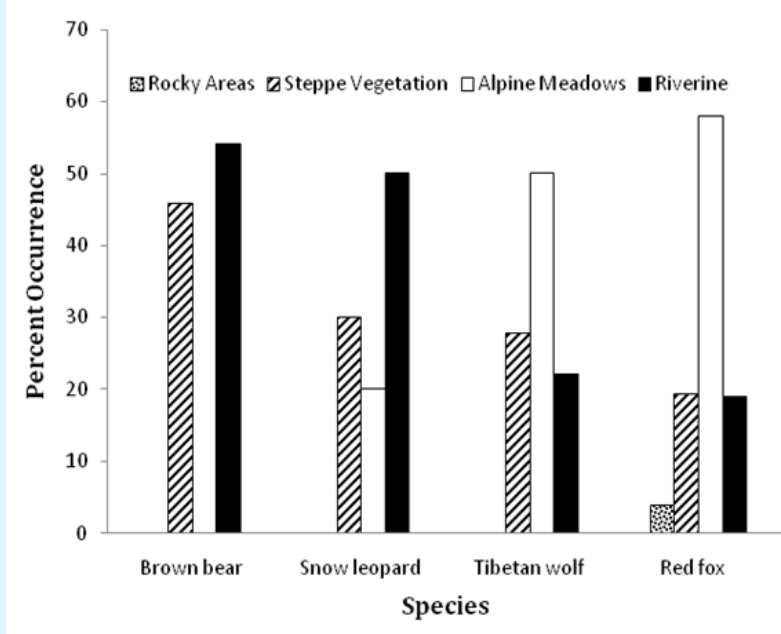

Figure 2: Percent occurrence of carnivore species in different habitat types in the Wakha Valley, Kargil.

\section{Birds}

A total of 45 bird species belonging to five orders and 19 families were recorded in the Wakha Valley (Table 2). This represented $17 \%$ of the total birds found in Ladakh.
Of the birds recorded, $49 \%$ were resident while $47 \%$ were summer visitors, $2 \%$ winter visitors and $2 \%$ were passage migrants. The Passeriformes represented by 36 species predominated the birds recorded (Table 3). 


\section{International Journal of Zoology and Animal Biology}

\begin{tabular}{|c|c|c|c|c|c|c|}
\hline Order & Family & Species & Resident & Summer Visitor & Winter Visitor & Passage Migrant \\
\hline Bucerotiformes & 1 & 1 & 0 & 1 & 0 & 0 \\
\hline Columbiformes & 1 & 5 & 4 & 1 & 0 & 0 \\
\hline Falconiformes & 1 & 1 & 0 & 1 & 0 & 0 \\
\hline Galliformes & 1 & 2 & 2 & 0 & 0 & 0 \\
\hline Passeriformes & 15 & 36 & 16 & 18 & 1 & 1 \\
\hline Total & 19 & 45 & 22 & 21 & 1 & 2 \\
\hline Percentage & & & 49 & 47 & 2 & 1 \\
\hline
\end{tabular}

Table 2: Birds of different species recorded during the survey in the Wakha Valley, Kargil.

\begin{tabular}{|c|c|c|c|c|c|}
\hline S. No. & Common Name & Scientific Name & Family & Order & Status \\
\hline 1 & Black-billed Magpie & Pica pica (Linnaeus, 1758) & Corvidae & Passeriformes & $\mathrm{R}$ \\
\hline 2 & Black Redstart & Phoenicurus ochruros (S. G. Gmelin, 1774) & Muscicapidae & Passeriformes & SV \\
\hline 3 & Blue Rock Thrush & Monticola solitaries (Linnaeus, 1758) & Muscicapidae & Passeriformes & SV \\
\hline 4 & Blue Throat & Luscinia svecica (Linnaeus, 1758) & Muscicapidae & Passeriformes & SV \\
\hline 5 & Blue Whistling Thrush & Myophonus caeruleus (Scopoli, 1786) & Muscicapidae & Passeriformes & $\mathrm{R}$ \\
\hline 6 & Brown Accentor & Prunella fulvescens (Severtsov, 1873) & Prunellidae & Passeriformes & $\mathrm{R}$ \\
\hline 7 & Brown Dipper & Cinclus pallasii (Temminck, 1820) & Cinclidae & Passeriformes & $\mathrm{R}$ \\
\hline 8 & Chukar Partridge & Alectoris chukar (J.E. Gray, 1830) & Phasianiadea & Galliformes & $\mathrm{R}$ \\
\hline 9 & Citrine Wagtail & Motacilla citreola (Pallas, 1776) & Motacillidae & Passeriformes & SV \\
\hline 10 & Common Kestrel & Falco tinnunculus (Linnaeus, 1758) & Falconidae & Falconiformes & SV \\
\hline 11 & Common Raven & Corvus corax (Linnaeus, 1758) & Corvidae & Passeriformes & $\mathrm{R}$ \\
\hline 12 & Common Rosefinch & Erythrina erythrina (Pallas, 1770) & Frangillidae & Passeriformes & SV \\
\hline 13 & Common Starling & Sturnus vulgaris (Linnaeus, 1758) & Sturnidae & Passeriformes & $\mathrm{R}$ \\
\hline 14 & Desert Wheatear & Oenanthe deserti (Temminck, 1825) & Muscicapidae & Passeriformes & SV \\
\hline 15 & Eurasian Collared Dove & Streptopelia decaocto (Frivaldszky,1838) & Columbidae & Columbiformes & SV \\
\hline 16 & Eurasian Golden Oriole & Oriolus oriolus (Linnaeus, 1758) & Oriolidae & Passeriformes & SV \\
\hline 17 & Eurasian Jackdaw & Corvus monedula (Linnaeus, 1758) & Corvidae & Passeriformes & WV \\
\hline 18 & European Goldfinch & Carduelis carduelis (Linnaeus, 1758) & Frangillidae & Passeriformes & SV \\
\hline 19 & Fire-front & Serinus pusillus (Pallas, 1811) & Fringill & Passeri & $\mathrm{R}$ \\
\hline 20 & Great Rosefinch & Carpodacus rubicilla (Guldenstadt, 1775) & Frangillidae & Passeriformes & SV \\
\hline 21 & Great Tit & Parus cinereus (Vieillot, 1818) & Paridae & Passeriformes & $\mathrm{R}$ \\
\hline 22 & Grey Wagtail & Motacilla cinerea (Tunstall, 1771) & Motacillidae & Passeriformes & $\mathrm{R}$ \\
\hline 23 & Hill Pigeon & Columba rupestris (Pallas, 1811) & Columbidae & Columbiformes & $\mathrm{R}$ \\
\hline 24 & Himalayan Snowcock & Tetraogallus himalayensis (G. R. Gray, 1843) & Phasianiadea & Galliformes & $\mathrm{R}$ \\
\hline 25 & Common Hoopoe & Upupa epops (Linnaeus, 1758) & Upupidae & Bucerotiformes & SV \\
\hline 26 & Horned Lark & Eremophila alpestris (Linnaeus, 1758) & Alaudidae & Passeriformes & $\mathrm{R}$ \\
\hline 27 & House Sparrow & Passer domesticus (Linnaeus, 1758) & Passeridae & Passeriformes & SV \\
\hline 28 & Kashmir Chiffchaff & Phylloscopus sindianus(W. E. Brooks, 1880) & Phylloscopidae & Passeriformes & SV \\
\hline 29 & Large-billed Crow & Corvus macrorhynchos (Wagler, 1827) & Corvidae & Passeriformes & $\mathrm{R}$ \\
\hline 30 & Long-tailed Shrike & Lanius schach (Linnaeus, 1758) & Laniidae & Passeriformes & SV \\
\hline 31 & Oriental Turtle Dove & Streptopelia orientalis (Latham, 1790) & Columbidae & Columbiformes & $\mathrm{R}$ \\
\hline 32 & Pied Wheatear & Oenanthe pleschanka (Lepechin, 1770) & Muscicapidae & Passeriformes & PM \\
\hline 33 & Red-billed Chough & Pyrrhocorax pyrrhocorax(Linnaeus, 1758) & Corvidae & Passeriformes & $\mathrm{R}$ \\
\hline 34 & Robin Accentor & Prunella rubeculoides (F. Moore, 1854) & Prunellidae & Passeriformes & $\mathrm{R}$ \\
\hline 35 & Rock Bunting & Emberiza cia (Linnaeus, 1766) & Emberizidae & Passeriformes & SV \\
\hline 36 & Rock Pigeon & Columba livia (J.F. Gmelin, 1789) & Columbidae & Columbiformes & $\mathrm{R}$ \\
\hline 37 & Rufous-naped Tit & Periparus rufonuchalis (Blyth, 1849) & Paridae & Passeriformes & SV \\
\hline 38 & Snow Pigeon & Columba leuconota (Vigors, 1831) & Columbidae & Columbiformes & $\mathrm{R}$ \\
\hline 39 & Tibetan Snowfinch & Montifringilla adamsi (Adams, 1859) & Passeridae & Passeriformes & SV \\
\hline
\end{tabular}




\section{International Journal of Zoology and Animal Biology}

\begin{tabular}{|c|c|c|c|c|c|}
\hline 40 & Wallcreeper & Tichodroma muraria (Linnaeus, 1766) & Sittidae & Passeriformes & R \\
\hline 41 & White Wagtail & Motacilla alba (Linnaeus, 1758) & Motacillidae & Passeriformes & SV \\
\hline 42 & White-winged Redstart & $\begin{array}{c}\text { Phoenicurus erythrogastrus (Guldenstadt, } \\
\text { 1775) }\end{array}$ & Muscicapidae & Passeriformes & R \\
\hline 43 & $\begin{array}{c}\text { White-capped Water } \\
\text { Redstart }\end{array}$ & Chaimarrornis leucocephalus (Vigors, 1831) & Muscicapidae & Passeriformes & SV \\
\hline 44 & Yellow-billed Chough & Pyrrhocorax graculus (Linnaeus, 1766) & Corvidae & Passeriformes & R \\
\hline 45 & Yellow Wagtail & Motacilla flava (Linnaeus, 1758) & Motacillidae & Passeriformes & SV \\
\hline
\end{tabular}

Table 3: Birds observed during the survey in the Wakha Valley, Kargil, Ladakh.

Passeriformes were recorded in all five habitat types whereas falconiformes were recorded in only two habitat types: steppe and riverine areas (Figure 3). Maximum bird species were however observed in the riverine and steppe vegetation. People reported sighting of Blacknecked Crane in the valley some 20 years ago. This could be true, as people could identify the species when a picture of the bird was shown to them. The people said that the pond where they had observed the crane has been subsumed by agricultural activities. Additionally they reported decrease in sightings of Passeriformes such as House Sparrow, Rose Finch, Redstart and Gold Finch to mention a few.

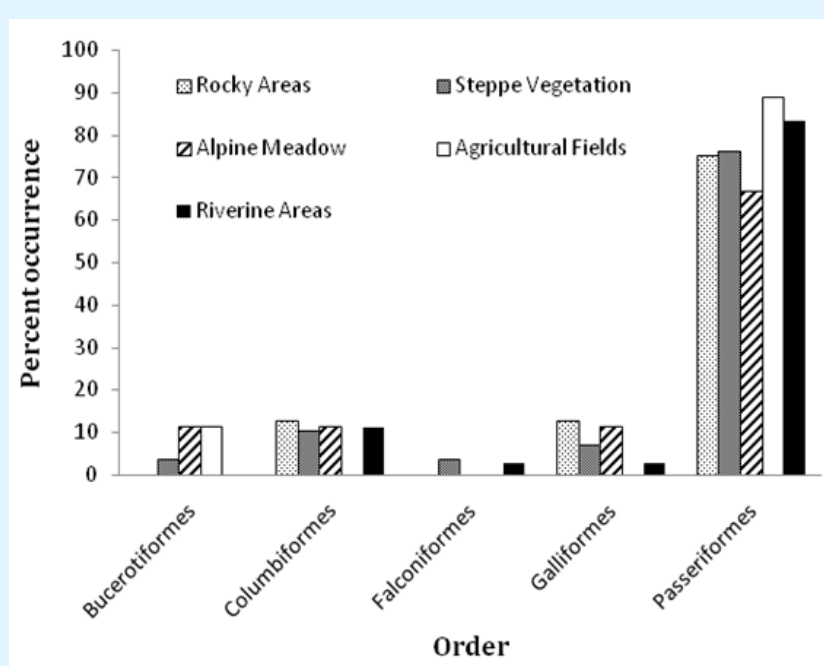

Figure 3: Percent occurrence of birds of different orders in varying habitat types in the Wakha Valley, Kargil.

\section{Discussion}

We recorded 12 species of wild mammals in the Wakha Valley. Ladakh urial and Asiatic ibex were the most prominent species observed. The ibex was observed in steeper areas with slopes steeper than 30 degrees whereas urial occurred in gentler areas with slope angle of $<30$ degrees [10,27]. Asiatic ibex and long-tailed marmot occurred in similar terrain type [28]. The average group size of ibex was less than 11, which is consistent with that reported in other parts of the Kargil district [23].
The mammalian carnivores that we recorded were red fox, Tibetan wolf and the snow leopard. We observed 8 individuals of red fox, while only the signs such as pugmarks, scrapes and scats were recorded of the other species. Snow leopard signs were always found near cliff base, along ridgelines or the base of over-hanging rocks. We recorded one omnivore: brown bear. Signs of this species were found mostly in the riparian and rocky areas. Bear use rocky areas as transitory routes hence their signs in this habitat type. Local people also reported the presence of the Eurasian otter, stone martin, Himalayan weasel, pikas and voles. However, we did not observe any of these species during the survey. 


\section{International Journal of Zoology and Animal Biology}

As far as the birds are concerned, we recorded equal number of residents and migratory birds. The birds recorded were dominated by Passeriformes, which is consistent with other reports on avifauna from the region $[2,21,22]$. Species composition in the area was similar to that recorded elsewhere in Ladakh. As almost half of the species recorded were summer visitors, it is pertinent to mention that the area serve as an important area for migratory birds. We observed maximum number of bird species in riverine habitats and agricultural fields. This is perhaps due to the season of the survey, which was carried out in May when other habitat types were still dry.

Talking to knowledgeable people in the area, we came to know that the major challenges for the mammal conservation are rapid infrastructure development, retaliatory killing of wild predators when the latter kill livestock, and competition of wild ungulates with domestic livestock. Feral dogs are also important threats to wild animals in the region. Lack of awareness among people about the importance of wildlife is also a major challenge. The resultant administrative apathy is a major stumbling block to wildlife conservation. The most despised wild animals are the brown bear and the snow leopard. Brown bear kills livestock as well as raid ration stores, while the snow leopard is notorious for getting inside livestock corrals and killing multiple livestock, especially sheep and goats in a single night.

For the birds, extensive use of artificial fertilizers and pesticides are the main threats, as a majority of the birds were recorded in agricultural habitats. People rely on artificial fertilizers and pesticides largely due to heavy subsidy on these products, and also due to global warming and associated surge in the population of pests. Furthermore, greater economic opportunities also have led to people keeping less livestock, the main source of manure. Another important threat to the birds is the modification of riverine habitats for agriculture and plantation.

\section{Acknowledgment}

We thank the people of Wakha Valley for their support during the field work. We thank the Village Sarpanch and Panch, Master Tsering and Akhone Abdullah for their invaluable help during the field work, and for arranging accommodation for the field team. We also thank the J\&K Wildlife Protection Department for their permission to carry out the survey. We are indebted to friends and staff members at the Department of Wildlife Science, Aligarh Muslim University for their constant support and encouragement during the research work. Departmental Research Committee at Department of Wildlife Science, AMU is acknowledged for approving the research work.

\section{References}

1. Namgail T, Tov YY (2009) Elevational range and timing of breeding in the birds of Ladakh: the effects of body mass, status and diet. Journal of Ornithology 150: 505-510.

2. Pfister O (2004) Birds and Mammals of Ladakh. Oxford University Press, New Delhi.

3. Namgail T (2009) Mountain ungulates of the TransHimalayan region of Ladakh, India. International Journal of Wilderness 15(2): 35-40.

4. Namgail $T$ (2005) Winter birds of the Gya-Miru Wildlife Sanctuary, Ladakh, Jammu and Kashmir, India. Indian Birds 1: 26-28.

5. Naoroji R, Sangha HS (2011) Threats to habitat and wildlife in Changthang and Rupshu areas of Ladakh: a case study at Hanle. Indian BIRDS 7(1): 2-6.

6. Adair FES (1895) Sports in Ladakh, Five letters from "The Field." London: Horace Cox, Windsor House, Bream's Buildings, E.C.

7. Schaller GB (1979) Mountain monarchs: Wild Sheep and Goats of the Himalaya. Chicago, Chicago University Press pp: 425.

8. Mallon DP (1991) Status and conservation of large mammals in Ladakh. Bio Cons 56: 101-119.

9. Fox JL, Nubru C, Chundawat RS (1991) The mountain ungulates of Ladakh, India. Biological Conservation 58(2): 167-190.

10. Raghavan B, Bhatnagar YV, Quresh Q (2003) Interactions between livestock and Ladakh urial (Ovis vignei vignei). Final report, The International Snow Leopard Trust.

11. Bhatnagar YV, Seth CM, Takpa J, Ul Haq S, Namgail T, et al. (2007) A Strategy for Conservation of Tibetan Gazelle Procapra picticaudata in Ladakh. Conservation and Society 5: 262-276.

12. Namgail T, Bagchi S, Mishra C, Bhatnagar YV (2008) Distributional correlates of the Tibetan gazelle in 


\section{International Journal of Zoology and Animal Biology}

northern India: Towards a recovery programme. Oryx 42: 107-112.

13. Namgail T, Fox JL, Bhatnagar YV (2007) Habitat shift and time budget of the Tibetan argali: The influence of livestock grazing. Ecol Res 22: 25-31.

14. Chundawat RS (1992) The ecological studies of snow leopard and its associated prey species in Hemis National Park, Ladakh, India. PhD thesis, University of Rajasthan.

15. Mallon DP (1984) The snow leopard in Ladakh. Int. Ped. Book of Snow leopards 4: 23-37.

16. Adam AL (1859) The birds of cashmere and Ladakh. Proceeding of the Zoological Society of London 27: 169-190.

17. Ludlow F (1920) Notes on the nidification of certain birds of Ladakh. Journal Bombay Natural History Society 27: 141-146

18. Wathen ML (1923) Ornithological notes from a trip in Ladak. Journal of the Bombay Natural History Society 29: 694-702.

19. Osmaston BB (1926) The birds of Ladakh. Ibis 12(1): 663-719.

20. Mishra C, Droz BH (1998) Avifaunal survey of TsoMoriri Lake and adjoining Nuro Sumdo wetlands in Ladakh, India Trans Himalaya. Forktail 14: 65-67.
21. Ahmed T, Khan A, Chandan P (2015) A pilot survey of the avifauna of Rangdum Valley, Kargil, Ladakh (Indian Trans-Himalaya). Journal of Threatened Taxa 7(6): 7274-7281.

22. Holmes PR (1986) Avifauna of the Suru River Valley. Ladakh. Forktail 2: 21-41.

23. Fox JL, Sinha SP, Chundawat RS (1992) Activity patterns and habitat use of ibex in the Himalaya Mountains of India. Journal of Mammology 73(3): 527-534.

24. Reshamwala HS, Shrotriya S, Bora B, Lyngdoha S, Rodolfo D, et al. (2017) Anthropogenic food subsidies change the pattern of red fox diet and occurrence across Trans-Himalayas, India. Journal of Arid Environments 150: 15-20.

25. Hartmann H (1997) A summarizing report on the phytosociological and floristical explorations India.

26. Grimmett R, Inskipp C and Inskipp T (1999) Pocket Guide to the Birds of the Indian Subcontinent. Oxford University Press, New Delhi.

27. Namgail T (2006) Winter habitat partitioning between Asiatic ibex and blue sheep in Ladakh, Northern India. J Mount Ecol 8: 7-13.

28. Namgail T, Van Wieren SE, Prins HHT (2013) Distributional congruence of mammalian herbivores in the Trans-Himalayan Mountains. Current Zoology 59(1): 116-124. 